\title{
Profilaktyka żywieniowa i żywienie w cukrzycowej chorobie nerek
}

\author{
Nutritional prevention and nutrition in diabetic kidney disease
}

\section{STRESZCZENIE}

Cukrzycowa choroba nerek określa powikłanie cukrzycy, które w wyniku utrzymującej się hiperglikemii doprowadza do zaburzeń czynności i zmian morfologicznych w nerkach. Choroba ta z biegiem czasu staje się coraz większym problemem klinicznym. Ze względu na klasyfikację cukrzycy jako choroby cywilizacyjnej i wysokie ryzyko powikłań ze strony nerek stanowi ogromny problem dla pacjentów, ponieważ często doprowadza do schyłkowej niewydolności nerek. Konsekwencje wiążące się z tym schorzeniem to przede wszystkim uciążliwe i bardzo kosztowne leczenie nerkozastępcze. Jednym z elementów prawidłowo prowadzonej terapii jest odpowiednio zaplanowany sposób żywienia. W pracy omówiono najistotniejsze kwestie związane z postępowaniem dietetycznym. Zwrócono uwagę na rolę poszczególnych składników odżywczych, ale także na znaczenie edukacji żywieniowej jako istotnego elementu postępowania dietetycznego. (Diabet. Klin. 2015; 4, 5: 183-188)

Słowa kluczowe: cukrzyca, cukrzycowa choroba nerek, żywienie

\section{ABSTRACT}

Diabetic nephropathy defines a complication of diabetes that as a result of persistent hyperglycemia

Adres do korespondencji:

dr inż. Anna Kościej

Wydział Ochrony Zdrowia

Śląska Wyższa Szkoła Medyczna

ul. Mickiewicza 29, 40-085 Katowice

e-mail: a.kosciej@gmail.com

Diabetologia Kliniczna 2015, tom 4, 5, 183-188

DOI: 10.5603/DK.2015.0021

Nadesłano: 29.09.2015

Przyjęto do druku: 05.10.2015 leads to dysfunction and the morphological changes in the kidney. This disease over time becomes more and more clinical problem. Due to the classification of diabetes as a civilization disease, and a high risk of complications from the kidney, is a huge problem for patients because it often leads to end-stage renal failure. The consequences of binding to the disease are mainly onerous and costly replacement therapy. One of the components of the properly conducted therapy is correctly planned diet. The paper discusses the most important issues associated with dietary behavior. Attention was drawn to the role of specific nutrients, but also the importance of nutrition education as an essential element of dietary proceeding. (Diabet. Klin. 2015; 4, 5: 183-188)

Key words: diabetes, diabetic kidney disease, nutrition

\section{Wstęp}

Cukrzycowa choroba nerek z biegiem czasu staje się coraz większym problemem klinicznym. Ze względu na klasyfikację cukrzycy jako choroby cywilizacyjnej i wysokie ryzyko powikłań ze strony nerek stanowi ogromny problem dla pacjentów, ponieważ często doprowadza do schyłkowej niewydolności nerek. Konsekwencje wiążące się z tym schorzeniem to przede wszystkim uciążliwe i bardzo kosztowne leczenie nerkozastępcze.

Aby uniknąć tego problemu, zahamować postępowanie choroby i jej powikłań, konieczne jest odpowiednie leczenie nefroprotekcyjne. Jednym z jego elementów jest właściwe postępowanie dietetyczne, które ma na celu odpowiednie odżywienie, dostarczenie niezbędnych składników odżywczych i eliminację produktów szkodliwych. Prawidłowo skomponowany jadłospis, wskazówki dotyczące żywienia oraz wykształcenie u pa- 
cjenta umiejętności własnego komponowania posiłków i przestrzegania zaleceń żywieniowych prowadzą do przedłużenia leczenia zachowawczego [1].

Celem pracy jest przybliżenie zagadnień związanych z postępowaniem dietetycznym i edukacyjnym w chorobach nerek będących powikłaniem cukrzycy. Praca zawiera zalecenia dietetyczne obejmujące przede wszystkim modyfikację czynników ryzyka postępu choroby.

\section{Cukrzycowa choroba nerek - przyczyny, przebieg i leczenie}

Cukrzyca to grupa chorób metabolicznych spowodowanych zakłóceniem wydzielania i/lub działania hormonu wysp trzustkowych, jakim jest insulina produkowana w trzustce. Defekt ten powoduje hiperglikemię, czyli podwyższone stężenie glukozy we krwi. Przewlekła hiperglikemia oddziałuje na narządy i układy, uszkadzając je poprzez upośledzenie ich czynności. Cukrzyca może prowadzić do szeregu powikłań, w tym: uszkodzenie serca, naczyń krwionośnych, a także nerek (nefropatia cukrzycowa) [2].

Cukrzycowa choroba nerek określa powikłanie cukrzycy, które w wyniku utrzymującej się hiperglikemii, doprowadza do zaburzeń czynności i zmian morfologicznych w nerkach. Takie zaburzenia z współistniejącym nadciśnieniem tętniczym (czynnik przyczynowy) powodują pogorszenie funkcji narządu i mają istotny wpływ na wzrost chorobowości i śmiertelności u osób chorujących na cukrzycę. Początkowo objawia się to mikroalbuminurią, która z czasem postępuje i prowadzi do makroalbuminurii mogącej powodować niewydolność nerek. Cukrzycową chorobę nerek kwalifikuje się do tzw. mikroangiopatycznych powikłań cukrzycy [1, 3].

W Europie chorzy z cukrzycową chorobą nerek stanowią 30\%, a w Stanach Zjednoczonych niemal $50 \%$ wszystkich pacjentów leczonych nerkozastępczo. Wśród chorych na cukrzycę częstość rozwoju mikroalbuminurii wynosi $10-30 \%$ po 20 latach trwania choroby. Prawdopodobieństwo wystąpienia niewydolności nerek jest zdecydowanie wyższe u pacjentów z cukrzycą niż u chorych cierpiących na inne schorzenia [1, 4]. Szacuje się, że rozwinie się ona u około $30-40 \%$ chorych z cukrzycą typu $1[1,5]$ i u około $15-20 \%$ chorych z cukrzycą typu 2 [6].

Hiperglikemia powoduje nadmierny napływ glukozy do wnętrza komórek nerkowych (komórek mezangium, śródbłonka i cewek) i wiele zmian metabolicznych. Początek procesu chorobowego objawia się przerostem nerek i nadmiernym przesączaniem z powodu zwiększonego przepływu osocza przez nerki. Podwyższone stężenie glukozy we krwi przyczynia się do zwiększenia współczynnika przesączania kłębuszko- wego (GFR, glomerular filtration rate) o 5-10\%. Nadmierne przesączenie prowadzi do utraty białka, głównie albumin, przenikającego przez kłębuszek i dostającego się do przestrzeni, w której wytwarza się mocz. Obecność albumin zwiększa ich wydalanie z moczem, prowadząc do mikroalbuminurii. Pojawienie się albumin powoduje spadek GFR wskutek zamykania się naczyń włosowatych tkanki łącznej kłębuszków nerkowych i tkanki śródmiąższowej. Dochodzi do zmniejszenia powierzchni przesączania kłębuszkowego i dalszego zmniejszania wskaźnika GFR. Następuje zwłóknienie cewek nerkowych będące wynikiem stanu zapalnego wywołanego białkiem gromadzącym się w komórkach nabłonka cewek. Białkomocz uszkadza cewki i tkankę śródmiąższową oraz prowadzi do bliznowacenia miąższu nerek, co jeszcze bardziej zmniejsza wartość GRF $[1,3,7]$.

W typowym przebiegu cukrzycowej choroby nerek rozmiar nerek jest prawidłowy lub nieco powiększony, co wyróżnia ją spośród innych postaci niewydolności nerek. Rozpoznanie jest jednak bardzo utrudnione ze względu na długi bezobjawowy przebieg choroby, szczególnie w początkowych stadiach. Choroba zostaje zidentyfikowana najczęściej dopiero wówczas, gdy doszło już do poważnego uszkodzenia nerek. Do najczęstszych objawów cukrzycowej choroby nerek należy ogólne osłabienie, brak apetytu, obrzęki, wysokie ciśnienie tętnicze $[1,8]$.

Jednym z podstawowych czynników ryzyka omawianego schorzenia jest nieleczone, ciągle podwyższone stężenie glukozy we krwi. Intensywne leczenie dietetyczne i farmakologiczne oraz dążenie do osiągnięcia wartości stężenia glukozy zbliżonych do prawidłowych opóźnia pojawienie się mikroalbuminurii, a także skutecznie hamuje postęp uszkodzenia nerek, zwalnia progresję z mikro- do makroalbuminurii. W kontroli glikemii należy dążyć do utrzymania stężenia glukozy przed posiłkiem w przedziale $80-120$ mg/dl, a wieczorem w zakresie 100-120 mg/dl.

Nadciśnienie tętnicze to kolejny czynnik, który bez odpowiedniego leczenia jest bardzo poważnym zagrożeniem sprzyjającym postępowaniu choroby. U chorych z cukrzycą typu 1 nadciśnienie tętnicze pojawia się wraz z postępem choroby, natomiast w cukrzycy typu 2 występuje ono "samoistnie" lub w wyniku innych chorób (np. miażdżyca w przebiegu otyłości i zaburzeń lipidowych). Udowodniono, że wysokie ciśnienie przyśpiesza rozwój nefropatii, istotnie przyczyniając się do zmniejszenia GFR. Zaleca się utrzymanie ciśnienia tętniczego na poziomie $<130 \mathrm{~mm} \mathrm{Hg}$ skurczowego i $<80 \mathrm{~mm} \mathrm{Hg}$ rozkurczowego.

Ponadto coraz więcej badań przeprowadzanych pod kątem charakterystyki czynników ryzyka wykazuje 
istotny wpływ czynników genetycznych na powikłania cukrzycy. Można do nich zaliczyć: geny wrażliwości na insulinę, geny nadciśnienia tętniczego, geny regulujące syntezę struktur zewnątrzkomórkowych.

Do czynników zwiększających ryzyko powikłań w cukrzycowej chorobie nerek zalicza się zaburzenia lipidowe. Ten typ zaburzeń istotnie wpływa na ryzyko powikłań sercowo-naczyniowych. Zaburzenia te charakteryzują się wzrostem stężenia cholesterolu frakcji LDL i obniżeniem stężenia cholesterolu frakcji HDL. Występują one bardzo często u chorych z wcześniej rozwiniętą chorobą wieńcową. Istotnym elementem zapobiegania zaburzeniom lipidowych jest zmniejszenie stężenia cholesterolu całkowitego, LDL oraz triglicerydów.

Istotne znaczenie w przypadku pacjentów z cukrzycową chorobą nerek ma także eliminacja używek — zwłaszcza tytoniu i alkoholu, powodujących postęp choroby $[1,3,9,10]$.

\section{Postępowanie dietetyczne w cukrzycowej chorobie nerek}

Prawidłowo opracowana dieta, dostosowana do indywidualnych potrzeb pacjenta jest bardzo istotnym elementem zarówno podczas leczenia cukrzycy, w przypadku której prawidłowe utrzymanie glikemii jest podstawowym elementem zahamowania rozwoju choroby i jej powikłań, jak i przy współistniejącej chorobie nerek, wpływając na zatrzymanie rozwoju ich uszkodzenia. Dieta powinna także zwiększyć efektywność kontroli ciśnienia tętniczego oraz zaburzeń lipidowych, które pogłębiają progresję cukrzycowej choroby nerek [1, 11]. Postępowanie dietetyczne nie ogranicza się tylko do opracowania odpowiedniej diety. Niezwykle istotną kwestią jest także edukacja pacjenta, modyfikacja stylu życia oraz, jeśli istnieje taka potrzeba, wprowadzenie aktywności fizycznej dostosowanej do możliwości pacjenta [11].

W postępowaniu dietetycznym należy uwzględnić właściwe zapotrzebowanie energetyczne, podaż białka, węglowodanów i tłuszczów, witamin i składników mineralnych, a także płynów. Każdy z tych elementów należy ustalać w zależności od typu cukrzycy, stopnia uszkodzenia nerek i rodzaju istniejących powikłań [1, 12].

Podstawową zasadą ułożenia odpowiedniej diety dla chorego z cukrzycową chorobą nerek jest ustalenie odpowiedniego zapotrzebowania energetycznego. Właściwa podaż kalorii zapewnia pokrycie wydatków energetycznych wynikających z podstawowej przemiany materii oraz aktywności fizycznej. Zapotrzebowanie powinno zostać dostosowane do typu cukrzycy, stopnia upośledzenia nerek, masy ciała, a także obecności chorób współwystępujących [12]. Przyjmuje się, że zapotrzebowanie energetyczne powinno wynosić około $35 \mathrm{kcal} / \mathrm{kg}$ należnej masy ciała/dobę u osób poniżej 60. roku życia, natomiast u osób powyżej 60 . roku życia 30-35 kcal/kg należnej masy ciała/dobę. Podane wartości dotyczą wszystkich stadiów cukrzycowej choroby nerek $[12,13]$. Dieta nie powinna być ubogokaloryczna, gdyż bez odpowiedniej ilości energii nie można bezpiecznie ograniczyć ilości białka [11].

U chorych z cukrzycą typu 2 i współistniejącą chorobą nerek często występuje otyłość. W 1. i 2. stadium choroby należy dążyć do redukcji masy ciała. Jej spadek bardzo korzystnie wpływa na kontrolowanie glikemii, zaburzeń lipidowych, a także ciśnienia tętniczego, co wiąże się z hamowaniem progresu uszkodzenia nerek. W celu uzyskania odpowiednich wartości wskaźnika masy ciała (BMI, body mass index) należy uzyskać ujemny bilans kaloryczny i/lub w miarę możliwości wprowadzić aktywność fizyczną. W kolejnych stadiach choroby nie należy wprowadzać deficytu kalorycznego, gdyż grozi to niedożywieniem, co w konsekwencji zwiększa śmiertelność. Dotyczy to również pacjentów dializowanych oraz bardzo często osoby z cukrzycą typu 1, u których celem diety jest najczęściej utrzymanie masy ciała [1, 12]

Poza ustaleniem odpowiedniej wartości energetycznej równie istotne jest zapewnienie odpowiednich ilości białka, węglowodanów i tłuszczów, niezbędnych do prawidłowego funkcjonowania organizmu i odciążenia uszkodzonego narządu [1, 3]

Ograniczenie podaży białka w diecie, którego nadmiar ma negatywny wpływ na funkcje czynnościowe nerek, to podstawowa metoda hamowania progresji choroby. Zwiększona podaż białka prowadzi do zwiększenia przesączenia kłębuszkowego, powoduje także wzrost ciśnienia wewnątrz kłębuszka nerkowego [3]. Rekomenduje się dietę, w której podaż białka powinna wynosić 0,8 g/kg/dobę [9]. Wraz ze stopniem zaawansowania choroby, a co się z tym wiąże zmniejszenia GFR, białko dalej się ogranicza do 0,6 g/kg/dobę, a nawet do 0,4 g/kg/dobę, wprowadzając także suplementację ketoanalogami aminokwasów. Wykazano, że dieta niskobiałkowa istotnie wpływa na zmniejszenie wystąpienia ryzyka kwasicy metabolicznej, co również w pewnym stopniu prowadzi do zwolnienia progresji choroby $[1,6]$. Zapotrzebowanie na białko wzrasta u chorych hemodializowanych i dializowanych otrzewnowo. Aby nie doszło do niedożywienia białkowo-energetycznego, a bilans azotowy utrzymywał się na bezpiecznym poziomie, należy dostarczyć białko w ilości około 1,2 g/kg/dobę. U chorych z zespołem nerczycowym jego podaż wynosi 0,8-1 g/kg/dobę. llość białka dostarczana do organizmu stanowi około $10 \%$ dziennej dawki kalorii. Połowę całej puli białka 
w dziennej racji pokarmowej powinno stanowić pełnowartościowe białko pochodzenia zwierzęcego [12]. Do najbardziej wartościowych źródeł białka można zaliczyć chude mięso (cielęcina, wołowina, jagnięcina), drób (kurczak, indyk), chude gatunki ryb (pstrąg, dorsz), wędliny (drobiowe, szynka bez tłuszczu, polędwica), mleko i przetwory (chudy twaróg, kefir, jogurt) $[2,14]$.

Węglowodany powinny zapewniać 50-60\% całodziennego zapotrzebowania energetycznego. W diecie istotnym elementem jest wprowadzenie węglowodanów złożonych, które są wolniej trawione i absorbowane, a tym samym korzystniejsze dla organizmu. Równocześnie należy ograniczać cukry proste i skrobię rafinowaną, które mają wysoki indeks glikemiczny i gwałtownie zwiększają stężenie glukozy we krwi. Dieta z przewagą węglowodanów złożonych daje możliwość kontroli gospodarki lipidowej i utrzymanie odpowiedniego stężenia glukozy. Podaż błonnika powinna wynosić 25-30 g/dobę [1, 11, 15]. Odpowiednim źródłem węglowodanów są pełnoziarniste produkty zbożowe (gruboziarnisty chleb, niełuskany ryż, grube kasze, makarony pełnoziarniste), ziemniaki, warzywa (marchew, seler, pomidory, ogórki, kalafior) [2, 14].

W cukrzycowej chorobie nerek często dochodzi do wystąpienia chorób związanych z zaburzeniami gospodarki lipidowej, na które składają się: podwyższone stężenie cholesterolu całkowitego, zwiększone stężenie triacylogliceroli, podwyższone stężenie cholesterolu frakcji LDL, przy jednoczesnym obniżeniu stężenia cholesterolu frakcji HDL. Tłuszcze powinny pokrywać 25-35\% dziennego zapotrzebowania na energię. Mając na względzie powyższe zaburzenia prowadzące do schorzeń sercowo-naczyniowych, istotnym działaniem podczas ustalania prawidłowej podaży tłuszczów jest ograniczenie do minimum tłuszczów nasyconych (< 7\% wartości energetycznej) i ograniczenie spożycia cholesterolu do < 200 mg/dobę. Należy także zwrócić uwagę na spożywanie produktów będących źródłem jedno- i wielonienasyconych kwasów tłuszczowych, które powinny pokrywać odpowiednio $20 \%$ oraz $10 \%$ całodziennego zapotrzebowania energetycznego $[1,11,13]$.

W przebiegu cukrzycowej choroby nerek może dojść do zwiększenia niedoborów witamin. Jest to spowodowane ścisłymi ograniczeniami dietetycznym, zaburzeniami wchłaniania, przyjmowaniem leków oraz dializoterapią. W celu wyeliminowania niedoboru witamin należy wprowadzić odpowiednią suplementację. W tabeli 1 przedstawiono dawki witamin w suplementacji u osób z przewlekłą chorobą nerek [16].

Problem niedoboru witaminy D3 jest szczególnie ważny ze względu na fakt, iż jej synteza kończy się w nerkach, w których jest przekształcana w formę ak-
Tabela 1. Zalecana dawka suplementacyjna witamin u osób z przewlekłą chorobą nerek [16]

\begin{tabular}{|c|c|}
\hline Witamina & $\begin{array}{c}\text { Zalecana dzienna } \\
\text { dawka suplementacyjna }\end{array}$ \\
\hline Witamina B1 (tiamina) & $1,1-1,2 \mathrm{mg}$ \\
\hline Witamina $B_{2}$ (ryboflawina) & $1,1-1,3 \mathrm{mg}$ \\
\hline Witamina $B_{5}$ (kwas pantotenowy) & $5 \mathrm{mg}$ \\
\hline Witamina $B_{6}$ (pirodoksyna) & $10 \mathrm{mg}$ \\
\hline Witamina $B_{12}$ (kobalamina) & $2,4 \mu \mathrm{g}$ \\
\hline Witamina C (kwas askorbinowy) & $75-90 \mathrm{mg}$ \\
\hline Witamina PP (niacyna) & $14-16 \mathrm{mg}$ \\
\hline Witamina H (biotyna) & $30 \mu \mathrm{g}$ \\
\hline Kwas foliowy & $1 \mathrm{mg}$ \\
\hline Witamina A (retinol) & Nie suplementować \\
\hline Witamina E (alfa-tokoferol) & $400-800 \mathrm{jm}$. \\
\hline Witamina D w postaci aktywnej & $0,25-1 \mu \mathrm{g}$ \\
\hline Witamina K & Nie suplementować \\
\hline
\end{tabular}

tywną. W czasie zaburzenia syntezy aktywnych postaci i niedoboru witaminy D3 dochodzi do upośledzenia wchłaniania wapnia, a to w konsekwencji prowadzi do wtórnej nadczynności przytarczyc i rozwoju osteodystrofii nerkowej. Suplementacja pozostałych witamin rozpuszczalnych w tłuszczach nie jest konieczna, lecz często rozważa się także zwiększone dawkowanie witaminy E [11].

Ze względu na częste ryzyko niedoborów i małe ryzyko przedawkowania zaleca się suplementację witamin rozpuszczalnych $w$ wodzie, przede wszystkim witaminy C i kwasu foliowego [13].

Do podstawowych funkcji nerek należy regulacja gospodarki wodno-mineralnej, a także utrzymanie równowagi kwasowo-zasadowej. W upośledzonych czynnościowo nerkach dochodzi do zaburzeń tych procesów, a związki mineralne w nich uczestniczące muszą podlegać kontroli [12].

W cukrzycowej chorobie nerek zmniejsza się zdolność wydalania sodu z organizmu. Jego nadmiar wywołuje pragnienie i zatrzymanie wody w organizmie, co w konsekwencji może prowadzić do obrzęków i zwiększenia ciśnienia tętniczego. Rekomenduje się spożycie sodu 1-3 g/dobę, czyli mniej niż 7,2 g soli. Należy unikać produktów bogatych w sód, takich jak: produkty w konserwach, słone przekąski, marynaty, koncentraty zawierające glutaminian sodu. Należy także ograniczyć dosalanie potraw; alternatywą może być doprawianie sokiem z cytryny lub stosowanie przypraw $[12,14]$.

Istotnym pierwiastkiem w większości wydalanym przez nerki jest potas. W pierwszych stadiach choroby stężenie potasu jest utrzymane na odpowied- 
nim poziomie. Kiedy dochodzi do postępu choroby (GFR < $30 \mathrm{ml} / \mathrm{min} / 1,73 \mathrm{~m}^{2}$ ), stężenie potasu wzrasta, co może doprowadzić do zaburzeń rytmu serca i zgonu. Dzienne spożycie potasu powinno mieścić się w granicach 1500-2000 mg [14]. Produkty zawierające dużą ilość potasu to orzechy, czekolada, kakao, ziemniaki, warzywa strączkowe.

Kolejnym składnikiem mineralnym, którego wydalanie w przewlekłej chorobie nerek ulega retencji i prowadzi do wtórnej czynności przytarczyc oraz wypłukania wapnia z kości, jest fosfor. Nerki wydalają około $70 \%$ tego pierwiastka. Ze względu na obecność fosforu w wielu produktach należy podawać leki wiążące fosforany. Podaż fosforu nie powinna przekraczać 1000 mg/dobę. Najczęściej jego dawka ustalana jest indywidualnie $[12,16]$.

Częstym zaburzeniem współistniejącym z chorobą nerek również w cukrzycy jest hipokalcemia, czyli niskie stężenie wapnia w surowicy krwi. Zaburzenie wchłaniania z powodu niedoboru aktywnej formy witaminy D czy restrykcje dietetyczne to podstawowe czynniki rozwoju hipokalcemii. Zaleca się spożywanie 1200-1600 mg wapnia na dobę [12]. Źródłem wapnia jest ser żółty, mleko, maślanka, kefir. W przypadku diety niskobiałkowej i ograniczeniu podaży fosforu dostarczenie odpowiedniej ilości wapnia sprawia trudność. Alternatywą jest przyjmowanie preparatów wapnia $[11,12,14]$

W przypadku cukrzycowej choroby nerek nierzadko obserwuje się niedobór żelaza, szczególnie u pacjentów dializowanych. W takiej sytuacji stosuje się preparaty żelaza, aby nie dopuścić do rozwoju niedokrwistości. Podaż ustalana jest indywidualnie do potrzeb pacjenta, natomiast u osób, które nie wymagają leczenia nerkozastępczego, spożycie żelaza z dietą powinno wynosić $8 \mathrm{mg} /$ dobę dla mężczyzn i 8-12 mg/dobę dla kobiet [11].

Dializoterapia może także powodować deficyty cynku. Zalecane dobowe spożycie to $10-15 \mathrm{mg}$ dla mężczyzn i 10 mg dla kobiet. Suplementację należy rozpocząć tylko w przypadku jawnych objawów.

Ze względu na obniżone wydalanie magnezu jego nadmiar gromadzi się w organizmie, doprowadzając do hipermagnezemii. Zaleca się, aby spożycie tego pierwiastka nie przekraczało 200-300 mg/dobę, dlatego też chory powinien unikać kukurydzy, grochu, orzechów, soi, pietruszki oraz koncentratu pomidorowego $[11,14]$.

\section{Edukacja żywieniowa jako istotny element postępowania dietetycznego}

Edukacja pacjentów ma bardzo istotne znaczenie ze względu na zwiększenie ryzyka wystąpienia niedo- żywienia białkowo-kalorycznego. Znaczy wpływ na obecność tego problemu ma zmniejszenie łaknienia, a w konsekwencji mniejsze ilości przyjmowanych pokarmów. Niedożywienie może być spowodowane także przyjmowaniem leków, stosowaniem nieprawidłowej diety, a także nasilać się przy złym stanie psychicznym chorych [11]. W tym zakresie edukacja powinna skupiać się na przedstawieniu pacjentowi zasad diety niskobiałkowej oraz zaleceń dotyczących wprowadzenia „dobrych tłuszczów” ze względu na zaburzenia gospodarki jelitowej, a także na ograniczeniu cukrów prostych na korzyść węglowodanów złożonych, co pozwoli uniknąć wysokich stężeń glukozy. W celu efektywniejszego wprowadzenia restrykcji dietetycznych warto sporządzić dla pacjenta listę produktów zalecanych oraz przeciwwskazanych. Aby zwiększyć efektywność pracy dietetyka, warto zlecić kilkudniowe zapisywanie produktów spożytych przez pacjenta, aby poznać jego nawyki żywieniowe [16]. Bardzo ważnym elementem jest motywowanie do stosowania diety poprzez eksponowanie płynących z tego korzyści, a także pokazanie związku między wprowadzoną dietą a samopoczuciem [1, 11]. Prawidłowo prowadzona edukacja daje pacjentowi większe poczucie kontroli nad sytuacją. Umożliwia to łagodzenie lęku związanego z chorobą i koniecznością zmian w żywieniu. Edukacja jest zatem niezbędna we wprowadzaniu i utrzymywaniu pozytywnych zmian $w$ diecie chorego [11]

\section{Podsumowanie}

Leczenie dietetyczne stanowi istotny element terapii cukrzycowej choroby nerek, będącej jednym z istotnych powikłań cukrzycy. Ustalenie właściwej diety, opracowanej indywidualnie do potrzeb pacjenta jest trudne. Z uwagi na liczne powikłania w czasie choroby poradnictwo powinno być prowadzone w sposób indywidualny. Przy ustaleniu zaleceń bardzo ważne jest uwzględnienie stadium choroby, szybkości jej progresji i towarzyszących powikłań. Wskazane jest także indywidualne opracowanie jadłospisu, prowadzenie szkoleń w zakresie sposobów przygotowywania potraw. Z tego względu w zespołach prowadzących chorych z cukrzycową chorobą nerek nie powinno zabraknąć dietetyka z kwalifikacjami.

\section{Oświadczenie o konflikcie interesów}

Autorzy nie zgłaszają konfliktu interesów.

\section{PIŚMIENNICTWO}

1. Czekalski S. Cukrzycowa choroba nerek (nefropatia cukrzycowa) i inne choroby nerek. Wyd. 2. Termedia, Poznań 2007.

2. Tatoń J., Czech A. (red.) Diabetologia. Wydawnictwo Lekarskie PZWL, Warszawa 2001 
3. Timothy C. Evans, Capell P. Nefropatia cukrzycowa. Diabetologia Praktyczna 2001; 2: 15-23.

4. Nowakowski A. Epidemiologia cukrzycy. Diabetologia Praktyczna 2002; 3: 181-185.

5. Grzeszczak W. Nefropatia cukrzycowa. Via Medica, Gdańsk 2003.

6. Korzeniowska K., Jabłecka A. Cukrzyca. Farmacja Współczesna 2008; 1 : 231-235.

7. Grzeszczak W. Cukrzyca - poważny problem nefrologiczny XXI wieku. Postępy Nauk Medycznych 2003; 26-39.

8. Traczyk W. Fizjologia człowieka w zarysie. Wydawnictwo Lekarskie PZWL, Warszawa 2000.

9. Stanowisko Amercian Diabetes Association. Nefropatia cukrzycowa. Diabetologia Praktyczna 2002; 3 (supl. A): A129-A134.

10. Milczarek A., Franek E. Odwracalność nefropatii cukrzycowej. Diabetologia Kliniczna 2013; 2: 131-135.

11. Pałubicki K., Kaczkan M., Rutkowski B., Małgorzewicz S. Edukacja żywieniowa pacjentów z przewlekłą chorobą nerek w okresie leczenia zachowawczego. Forum Nefrologiczne 2011; 4: 306-312.
12. Franek E., Grzeszczak W. Postępowanie dietetyczne u chorych nerek. Postępy Nauk Medycznych 2013; 224-228.

13. Czekalski S., Rutkowski B., Małgorzewicz S., Dębska-Ślizień A. Stanowisko Zespołu Krajowego Konsultanta w dziedzinie Nefrologii dotyczące stosowania ketoanalogów aminokwasów i roztworu aminokwasów w leczeniu niedożywienia i zapobieganiu mu u dorosłych chorych z przewlekłą chorobą nerek. Forum Nefrologiczne 2011; 4: 183-188.

14. Ciborowska H., Rudnicka A. Dietetyka. Żywienie zdrowego i chorego człowieka. Warszawa, Wydawnictwo Lekarskie PZWL 2014.

15. Kucharska E. Cukrzyca typu drugiego - kryteria rozpoznawania, prewencja i cele terapeutyczne, w świetle wyników badań i wytycznych American Diabetes Association. Przegląd Lekarski 2013; 404-406.

16. Rutkowski B., Małgorzewicz S., Łysiak-Szydłowska W. Stanowisko dotyczące rozpoznawania oraz postępowania w przypadku niedożywienia dorosłych chorych z przewlekłą chorobą nerek. Forum Nefrologiczne 2010; 3: 138-142. 